\title{
$\beta 2$-adrenergic receptor functionality and genotype in two different models of chronic inflammatory disease: Liver cirrhosis and osteoarthritis
}

\author{
REYES ROCA $^{1}$, PABLO ESTEBAN ${ }^{1}$, PEDRO ZAPATER ${ }^{2,3}$, MARÍA-DEL-MAR INDA $^{4}$, ANNA LUCIA CONTE ${ }^{1}$, \\ LAURA GÓMEZ-ESCOLAR ${ }^{5}$, HELENA MARTÍNEZ ${ }^{6}$, JOSÉ F. HORGA ${ }^{3}$, JOSÉ M. PALAZON ${ }^{5}$ and ANA M. PEIRÓ ${ }^{3,4}$ \\ ${ }^{1}$ Occupational Observatory, Miguel Hernández University (UMH) of Elche, 03202 Elche; \\ ${ }^{2}$ CIBERehd, Carlos III Health Institute, 28029 Madrid; ${ }^{3}$ Clinical Pharmacology, General Hospital of Alicante; \\ ${ }^{4}$ Neuropharmacology on Pain (NED) Research Group, ISABIAL-FISABIO, General Hospital of Alicante; \\ ${ }^{5}$ Liver Unit, General Hospital of Alicante, 03010 Alicante; ${ }^{6}$ Clinical R\&D Area, Bioiberica S.A., 08029 Barcelona, Spain
}

Received June 12, 2017; Accepted September 28, 2017

DOI: $10.3892 / \mathrm{mmr} .2018 .8820$

\begin{abstract}
The present study was designed to investigate the functional status of $\beta 2$ adrenoceptors ( $\beta 2 \mathrm{AR})$ in two models of chronic inflammatory disease: Liver cirrhosis (LC) and osteoarthritis (OA). The $\beta 2 A R$ gene contains three single nucleotide polymorphisms at amino acid positions 16, 27 and 164 . The aim of the present study was to investigate the potential influence of lymphocyte $\beta 2 \mathrm{AR}$ receptor functionality and genotype in $\mathrm{LC}$ and $\mathrm{OA}$ patients. Blood samples from cirrhotic patients $(\mathrm{n}=52$, hepatic venous pressure gradient $13 \pm 4 \mathrm{mmHg}$, CHILD $7 \pm 2$ and MELD $11 \pm 4$ scores), OA patients ( $\mathrm{n}=30,84 \%$ Kellgren-Lawrence severity 4 grade, $14 \%$ knee replacement joint) and healthy volunteers as control group $(n=26)$ were analyzed. Peripheral blood mononuclear cells (PBMC) were isolated from whole blood and basal and isoproterenol induced adenylate cyclase activity (isoproterenol stimulus from $10^{-9}$ to $10^{-4} \mathrm{mM}$ ), and $\beta 2 A R$ allelic variants (rs1042713, rs1042714, rs1800888) were determined. $\beta 2 \mathrm{AR}$ functionality was decreased in the two different models of chronic inflammatory disease studied, OA (50\% vs. control) and LC (85\% vs. control). In these patients, the strength of the $\beta 2 A R$ response to adrenergic stimulation was very limited. Adrenergic modulation of PBMC function through the $\beta 2 \mathrm{AR}$ stimulus is decreased in chronic inflammatory processes including LC and OA, suggesting that the adrenergic system may be important in the development of these processes.
\end{abstract}

Correspondence to: Dr Ana M. Peiró, Neuropharmacology on Pain (NED) Research Group, ISABIAL-FISABIO, General Hospital of Alicante, Pintor Baeza, 12, 03010 Alicante, Spain

E-mail: peiro_ana@gva.es

Key words: $\beta 2$ adrenoceptors, liver cirrhosis, osteoarthritis, polymorphisms, isoproterenol, cAMP

\section{Introduction}

The role of the sympathetic nervous system (SNS) in inflammation is still not completely understood, although it is well known that disturbed interaction between both contributes to pathogenic chronic inflammatory diseases $(1,2)$. Evidence for the possibility of such interaction have been reinforced since the discovery of the expression of beta-2-adrenergic receptor $(\beta 2 \mathrm{AR})$ on $\mathrm{T}$ and $\mathrm{B}$ lymphocytes, macrophages, natural killer cells and neutrophils (3-6). Coexistence of all $\beta$ adrenoceptors $(\beta \mathrm{AR})$ subtypes has been reported in human peripheral blood mononuclear cells (PBMC) and erythrocytes (7), but lymphocyte $\beta 1 \mathrm{AR}$ and $\beta 3 \mathrm{AR}$ functionality in these cells has not been evidenced yet $(8,9)$. Stimulation of PBMC $\beta 2 \mathrm{AR}$ by catecholamines or selective pharmacologic ligands differentially regulates activity depending on cell activation and differentiation state, molecular signalling pathway and cytokine microenvironment.

Since $\beta 2 A R$ activity on circulating mononuclear cells is related to the level of $\beta 2 \mathrm{AR}$ activity on solid tissues cells, such as heart and skeletal muscle, mononuclear cells could be used as markers to evaluate development and progression of systemic $\beta 2 \mathrm{AR}$ (10). Recent studies suggested that $\beta 2 \mathrm{AR}$ modulation could be relevant in the development of joint diseases as rheumatoid arthritis (RA) (11-14), adjuvant-induced arthritic (AA) (15), and immune hepatitis $(16,17)$. Thus, two different models of chronic inflammatory diseases were selected (osteoarthritis (OA) and liver cirrhosis (LC)) to study the potential relation between their progression and PBMC $\beta 2 \mathrm{AR}$ functionality and genotype.

$\mathrm{OA}$ is the most common articular disorder characterized by chronic inflammation of the joint lining. Although OA inherently lacks the large scale systemic inflammatory response that is a hallmark in rheumatoid arthritis (RA), this is suggestive of low activation grade. In OA, the innervation pattern of sympathetic and sensory nerve fibres is altered in adult joint tissues and bone (18). It is now believed that synovial inflammatory changes in OA are associated with massive destruction of capillary and neuronal network with preponderance of 
sympathetic over sensory fibres. This promotes an increase in articular vessels adrenoceptor type towards $\beta 2$ AR $(19,20)$. Osteoblasts, osteoclasts, mesenchymal stem cells, synovial fibroblasts, and different types of chondrocytes produce distinct subtypes of adrenoceptors, receptors for vasointestinal peptide, for substance $\mathrm{P}$ and calcitonin gene-related peptide. Even more, cartilage integrity is maintained by a balance from cytokine-driven anabolic and catabolic processes (21). In fact, a novel OA treatment consists in the use of biological molecules with antiinflammatory properties $(22,23)$.

Cirrhosis causes $90 \%$ of portal hypertension in the Western world. This in turn triggers the formation of varices which are present in $30 \%$ of patients with compensated cirrhosis and $60 \%$ of those with decompensated cirrhosis (24). In an attempt to maintain effective circulating volume, endogenous vasoconstrictor systems as adrenergic are recruited. Adrenergic system releases catecholamines as adrenaline, which binds to $\alpha$ (vasoconstrictor) and $\beta$ (vasodilator) adrenoceptors. Engagement of the $\beta 2 \mathrm{AR}$ activates a cascade of signalling intermediates, including $\mathrm{CAMP}$ and protein kinase $\mathrm{A}$, leading to the phosphorylation of cellular proteins including transcription factors that mediate metabolic processes and gene expression (25). Currently the most widely used modalities to prevent variceal bleeding in LC patients are drugs as propranolol, a non-selective beta-blocker (26-28). However, the prevalence of patients 'non-responders' ranges between 30 and 60\%, suggesting changes in the functional state of $\beta A R$ receptors (29).

An interesting possibility is that underlying genetic $\beta 2 A R$ variability is involved in participant's efficacy of beta-blockers treatment (30). Three functionally relevant $\beta 2 A R$ gene single-nucleotide polymorphisms (SNPs) (Arg16Gly, rs1042713; Gln27Glu, rs1042714; Thr164Ile, rs1800888) have been associated with joint disorder, functional gastrointestinal disorders playing an important role in vascular regulation (31-34) and bronchial smooth muscle tone (35). In particular, Gln $27 G l u$ variant is associated with bone health (36), RA $(37,38)$, functional gastrointestinal diagnoses and bowel symptoms severity (39).

We analyzed $\beta 2$ AR functionality and genotype (rs1042713, rs1042714, rs1800888) in PBMC in patients diagnosed with OA and LC.

\section{Materials and methods}

Patients. A total of $30 \mathrm{OA}$ and 52 LC patients, together with 26 healthy volunteers participated in the study. Blood samples were drawn from anterocubital vein in the morning.

Ethical approval. Protocol was approved by the Clinical Research Ethics Committee of Alicante Department of Health, General Hospital (Alicante, Spain). All participants signed informed consent before enrolment, and the study was performed according to the Declaration of Helsinki.

OA patients. Patients from Primary Care of Alicante General Hospital Department of Health with knee OA were included in this study.

The inclusion criteria were as follows: Ages ranging from 50 to 80 years; diagnosis of knee OA according to the criteria established by the American College of Rheumatology (ACR) using history, physical examination and radiographic findings, knee X-rays in the last 12 months and a Kellgren-Lawrence (KL) OA grade of 2 or more, based on the radiological severity (grade 1, questionable narrowing of joint space and possible osteophytic lipping; grade 2, definite osteophytes and possible narrowing of joint space; grade 3 , moderate multiple osteophytes, definite narrowing of joints space, some sclerosis, and possible deformity of bone contour; and, grade 4, large osteophytes, marked narrowing of joint space, severe sclerosis, and definite deformity of bone contour) (40).

Patients with infections, inflammatory diseases, malignancies or patients using $\alpha$ - or $\beta$-adrenergic receptor agonists or antagonists were excluded from the study.

Cirrhotic patients. Patients from Liver Unit of Alicante Department of Health, General Hospital with LC were included in this study.

The inclusion criteria were as follows: Ages ranging from 40 to 80 years; diagnosis of cirrhosis according to the criteria established by Spanish Association for the Study of the Liver (AEEH) and the Biomedical Research Network Center for Liver and Digestive Diseases (CIBERehd) (41): Either liver biopsy or unequivocal clinical, imaging and biochemical findings (e.g., complete blood cell count, serum chemistries, liver function test, and coagulation studies).

None of the patients had an established transjugular intrahepatic portosystemic shunt (TIPS). Patients with systolic blood pressure $<100 \mathrm{mmHg}$ bradycardia (heat rate $<50 / \mathrm{min}$ ), obstructive airway disease or other contraindications for treatment with propranolol were excluded from the study.

Patients were classified in two groups: Under prophylaxis or treatment of first upper gastrointestinal bleeding episode ('primary prophylaxis') or prophylaxis of recurrent bleeding ('secondary prophylaxis'). As non-bleeding varices are generally asymptomatic, high hepatic venous pressure gradient (HVPG) is the clinical gold standard for risk of formation prediction $(>12 \mathrm{mmHg}$ ) or rebleeding (HVPG $>20 \mathrm{mmHg}$ ) and to predict the response to $\beta$ blocker antagonists during treatment of portal hypertension ( $>20 \%$ fall from baseline of portal pressure). Hence HVPG clinical routinely monitoring allow the identification of patients who will be effectively protected against the risk of bleeding (labeled as 'responder') and those who, by not achieving a HVPG reduction by $20 \%$ of baseline or to $\leq 12 \mathrm{mmHg}$, present a very high risk of bleeding ('non-responders'). LC patients clinical data is presented in Table I.

In patients with previous variceal bleeding, investigations were made at least 7 days after the complete recovery of bleeding.

Controls subjects. A total of 26 healthy controls were recruited through blood donors from the same geographical areas as patients, and were matched to patients according ethnicity (at least 2 generations from the same area). None of the subjects in the healthy control group had any clinically significant abnormality shown by routine history, physical examination, or laboratory tests.

Determination of basal and stimulated intracellular cAMP. PBMC were isolated from EDTA venous blood by Percoll density gradient centrifugation. Activation of $\beta 2 A R$ leading 
Table I. Cirrhotic patient's demographic and clinical data.

\begin{tabular}{|c|c|c|}
\hline Clinical data & $\begin{array}{c}\text { Cirrhotic } \\
\text { primary }(n=22)\end{array}$ & $\begin{array}{c}\text { Cirrhotic } \\
\text { secondary }(n=30)\end{array}$ \\
\hline Ascites (yes/no) & $5 / 17$ & $14 / 17$ \\
\hline HDA & $2 / 20$ & $27 / 3$ \\
\hline Previous treatment with beta-blockers (yes/no) & $2 / 20$ & $16 / 14$ \\
\hline Total bilirubin (mg/dl) & $1,31 \pm 0.9$ & $1,64 \pm 0.8$ \\
\hline Serumalbumin (g/dl) & $3,49 \pm 0.7$ & $3,18 \pm 0.4$ \\
\hline Quick (\%) & $76 \pm 16$ & $68 \pm 14$ \\
\hline Creatinine (mg/dl) & $0,9 \pm 0,4$ & $0,8 \pm 0,2$ \\
\hline Hemoglobin (g/dl) & $13,02 \pm 2,1$ & $11,75 \pm 2,2$ \\
\hline Hematocrit $(\%)$ & $39 \pm 6$ & $36 \pm 6$ \\
\hline Platelets $\left(10^{3} / \mathrm{mm}^{3}\right)$ & $102 \pm 58$ & $91 \pm 51$ \\
\hline Glucose (mg/dl) & $113 \pm 51$ & $106 \pm 28$ \\
\hline Systolic arterial pressure (mmHg) & $128,0 \pm 17,7$ & $130,2 \pm 18,7$ \\
\hline Diastolic arterial pressure (mmHg) & $81,7 \pm 10,7$ & $77,2 \pm 12,2$ \\
\hline Heartrate $(\mathrm{bpm})$ & $74,6 \pm 16,6$ & $74,5 \pm 11,3$ \\
\hline Wedged hepatic venous pressure (mmHg) & $22,9 \pm 5,4$ & $25,4 \pm 4,2$ \\
\hline Free hepatic venous pressure (mmHg) & $8,1 \pm 3,8$ & $8,8 \pm 3,7$ \\
\hline Hepatic venous pressure gradient pre (mmHg) & $15 \pm 4,9$ & $17 \pm 3,3$ \\
\hline Hepatic venous pressure gradient post (mmHg) & $12 \pm 3,6$ & $15 \pm 4,3$ \\
\hline
\end{tabular}

to an increase in the intracellular level of cyclic adenosine monophosphate (cAMP, pmol/ml/10 ${ }^{6}$ cells) by increasing adenylate-cyclase (AC) activity was evaluated in duplicates by cAMP determination using a competitive Enzyme Immunoassay (EIA) according to laboratory procedures and manufacturer guidelines (Cayman Chemical Company, Ann Arbor, MI, USA).

Cells were counted in a Coulter Counter and with a Neubauer chamber. Viability was determined by trypan blue exclusion and ranged between 94-98\%. Cells were incubated as described by Sondergaard et al (42). Aliquots of $1 \times 10^{6} \mathrm{PBMC}$ were rinsed with Phosphate-buffered saline (1x PBS, $\mathrm{pH} 7.4$, containing $135 \mathrm{mM} \mathrm{NaCl}, 5.4 \mathrm{mM} \mathrm{KCl}, 1.4 \mathrm{mM} \mathrm{MgSO}_{4}$, $1.4 \mathrm{mM} \mathrm{CaCl}_{2}, 0.18 \mathrm{mM}$ sodium phosphate) and $3 \%$ (wt/vol) of bovine serum albumin (BSA) fraction V (Sigma-Aldrich; Merck KGaA, Darmstadt, Germany) (PBS-BSA) at room temperature. Phosphodiesterases were inhibited by preincubation at $37^{\circ} \mathrm{C}$ for $30 \mathrm{~min}$ with $1 \mathrm{mM}$ isobutyl-methyl-xanthine (IBMX) (Sigma-Aldrich; Merck KGaA). Then, cells were stimulated with different concentrations of isoproterenol (ISO) ranging from $10^{-9}$ to $10^{-4} \mathrm{mM}$ or vehicle for $15 \mathrm{~min}$. Stimulation was stopped at $100^{\circ} \mathrm{C}$ water bath for $3 \mathrm{~min}$. Samples were centrifuged for $5 \mathrm{~min}$ at $3500 \mathrm{rpm}$ and disrupted by sonication 3x15 sec (model SM25E-MT; Branson Ultrasonics Corporation, Geneva, Switzerland). Lysates were immediately frozen and stored at $-80^{\circ} \mathrm{C}$ until EIA analysis was performed as described previously.

On the day of the assay, samples were thawed at room temperature for $25-30 \mathrm{~min}$ and centrifuged at $4^{\circ} \mathrm{C}$ at 3,500 rpm for $10 \mathrm{~min}$ to remove insoluble material. cAMP was measured in the supernatant using a EIA. cAMP increase was calculated by subtraction of values determined in IBMX preincubated samples. All assays were performed in duplicate.
DNA extraction and beta-adrenergic genotyping. Blood samples from OA and LC patients and healthy controls were collected and genomic DNA was extracted from isolated PBMC using QIAamp ${ }^{\circledR}$ DNA Midi Kit according to manufacturer's instructions.

Genomic DNA was genotyped for SNPs within the $\beta 2 A R$ gene locus. Three SNPs with high frequency of polymorphism in the human population ( $>20 \%$ prevalence) and located within the coding region for gene were chosen. The known functional SNP rs1042713, rs1042714 and rs1800888 are well-studied common non-synonymous SNPs $(43,44)$.

$\beta 2 A R$ genotype at positions 16,27 and 164 was determined by polymerase chain reaction (PCR) and sequenced by Thermosequenase Primer Cycle kit (Amersham Pharmacia Biotechnology, Piscataway, NJ, USA). PCR was performed in a final volume of $25 \mu \mathrm{l}$ containing 100-200 ng DNA, $0.2 \mathrm{mM}$ of each dNTP, $1 \mathrm{X}$ de reaction buffer $(50 \mathrm{mM} \mathrm{KCl}$ and $20 \mathrm{mM}$ Tris- $\mathrm{HCl}, \mathrm{pH} 8.4), 1.5 \mathrm{mM} \mathrm{MgCl}_{2}, 1 \mathrm{U}$ Taq DNA polimerase, $10 \% \mathrm{DMSO}$ and $200 \mathrm{nM}$ of each primer. Temperature cycling was $94^{\circ} \mathrm{C}$ for $30 \mathrm{sec}, 61^{\circ} \mathrm{C}$ for $45 \mathrm{sec}$, and $72^{\circ} \mathrm{C}$ for $45 \mathrm{sec}$ for 30 cycles. In total, $10 \mu \mathrm{l}$ of the PCR products were visualized on a $1 \%$ agarose gel stained with ethidium bromide. Computer analysis of all SNP combinations in the human EST database (dbEST release 030405, 6,053,112 human entries) was performed using BLAST (National Library of Medicine, Bethesda, MD, USA). Complete nucleotide sequence of $\beta 2 A R$ gene was used (NM 000024) to design the primers (Primer 3; UCSD, San Diego, CA, USA).

Western blotting. To determine whether cAMP concentration changes in PBMC from patients was associated with variations in immunodetectable $\beta 2 \mathrm{AR}$ protein, quantitative Western blotting analysis was performed. 
After treatment with isoproterenol, cells were lysed and protein was extracted using RIPA buffer $(50 \mathrm{mM}$ Tris- $\mathrm{HCl}$ $\mathrm{pH}$ 7.4; $150 \mathrm{mM} \mathrm{NaCl}, 1 \mathrm{mM}$ EDTA, $0.25 \%$ Na-deoxycholate, $1 \%$ NP-40, $1 \mathrm{mM}$ PMSF, $1 \mathrm{mM}$ sodium orthovanadate, $1 \mu \mathrm{g} / \mathrm{ml}$ leupeptin, $1 \mu \mathrm{g} / \mathrm{ml}$ aprotinin, and $1 \mu \mathrm{g} / \mathrm{ml}$ pepstatin). Protein concentration was determined by BCA assay and samples were separated on $12 \%$ SDS-PAGE gels, and transferred onto Hybond-enhanced chemiluminescence (ECL) nitrocellulose membranes. Membranes were probed with antibodies against 32AR (R11E1, sc-81577; Santa Cruz Biotechnology, Inc., Dallas, TX, USA) of human origin. Protein bands were observed using ECL and specific bands were detected with X-film according to procedures of Proteomics and Genomics Division, Research Technical Facility of University of Alicante (Alicante, Spain).

Spot detection and quantification was performed using Progenesis Same Spots software according to manufacturer's instructions (Nonlinear USA,. Inc., Durham, NC, USA). Two individual gel replicates from each subject were used for the analysis. Results were expressed as relative arbitrary units (AU) according to procedure previously described (45), using as standard samples from 4 healthy subjects. GAPDH was used as endogenous control.

Statistical analysis. Quantitative data is expressed as mean \pm standard deviation (SD). Differences between groups were analysed using the T-Student or non-parametric Mann-Whitney U-test according to normality. Qualitative variables are expressed as frequency or percentage and differences between groups were evaluated using $\chi^{2}$ test. A comparison of independent single variables between the groups was calculated by one way analysis of variance (ANOVA) followed by Turkey's procedure. When normality test failed, Kruskal-Wallis one-way ANOVA on ranks was used. A two-tailed $\mathrm{P}<0.05$ was considered to indicate a statistically significant difference.

\section{Results}

Patients and control subjects. Thirty OA patients (age, $70 \pm 8$ years; female, $78 \%$; median (min, max) OA duration, 6 (1-29) years) were included in this study. A total of $12 \%$ were diabetic, $14 \%$ hypertensive, $8 \%$ dislipemic and 9\% BMI $>30 \mathrm{~kg} / \mathrm{m}^{2}$. Mainly category of KL radiological severity was 3-4 (90\%) grades and $15(54 \%)$ patients required knee joint replacement (76\% KL grade 4). Regular current use of analgesic (acetaminophen, dipyrone), and non-steroidal anti-inflammatory drugs (NSAIDs: Ibuprofen, naproxen or celecoxib) was very common (21 and $50 \%$, respectively), followed by chondroitin sulphate (12\%), glucosamine (6\%) and tramadol (2\%).

A total of 52 LC patients (age, $54 \pm 11$ years; females, $13.5 \%$ ) were submitted to the hospital clinic for HVPG determination and were included in the study. Alcohol was actively consumed by $11.5 \%$ of patients. Scores for Model for End-stage Liver Disease (MELD) were $11 \pm 4$ and Child-Pugh $7 \pm 2$, respectively. In total, $37 \%$ patients were previously treated with beta-blockers and $50 \%$ exhibited clinical response to propranolol (46).

A total of 26 healthy human volunteers (aged $59 \pm 13$ years; female $50 \%$ ) participated in the present study. They had normal blood cell counts, normal liver and kidney function test results, and normal findings on physical examination.
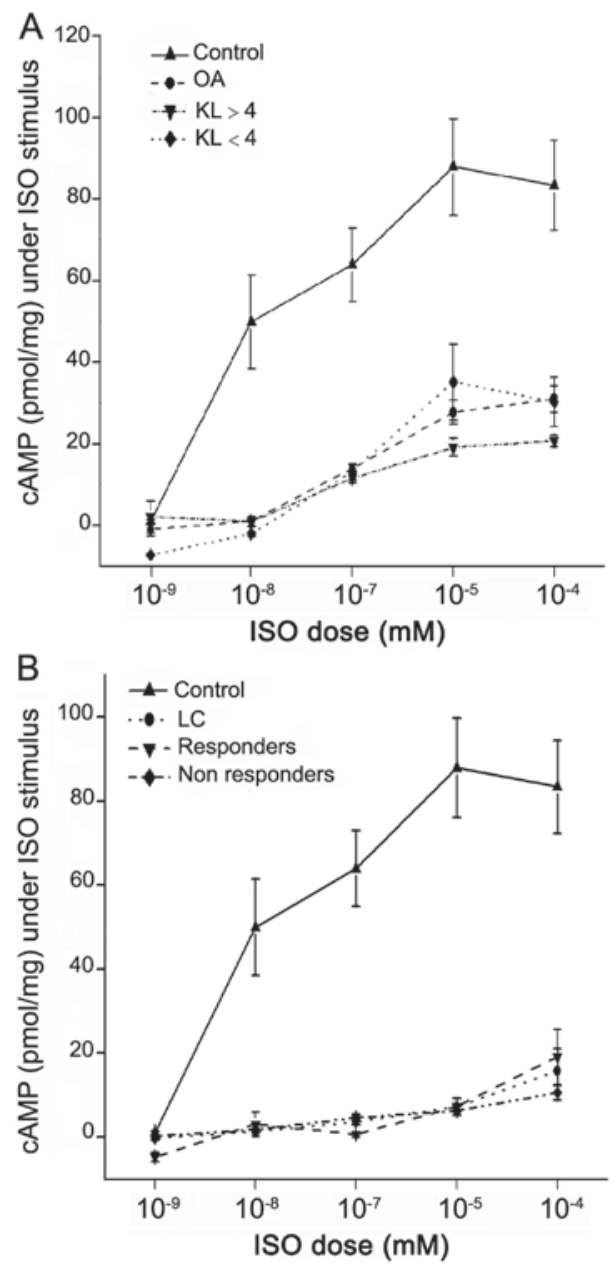

Figure 1. cAMP increase induced by isoproterenol (ISO) treatment in peripheral blood mononuclear cells (PBMC) in (A) osteoarthritis (OA) and (B) liver cirrhosis (LC) patients. Cells were incubated with ISO at different concentrations at room temperature for $30 \mathrm{~min}$. Each data point represents mean ( \pm standard deviation) of two wells (controls, 26 healthy volunteers; OA, 30 0steoarthritis patients; LC, 52 portal hypertension patients; ISO, 10 ${ }^{-9}$ to $10^{-4} \mathrm{mM}$; KL, OA Kellgren-Lawrence severity 4 grade).

Basal and stimulated intracellular cAMP. PBMC from control group stimulated with different concentrations of isoproterenol $\left(10^{-9}\right.$ to $\left.10^{-4} \mathrm{mM}\right)$, showed a significant increase in cAMP production in a dose-dependent manner with a maximum response between $10^{-5}$ to $10^{-4} \mathrm{mM}$ (Fig. $1 \mathrm{~A}$ and $\mathrm{B}$ ). Isoproterenol induced a significantly lower increase in cAMP concentration in OA and LC patients $\left(44 \pm 28\right.$ and $14 \pm 15.5 \mathrm{pmol} / \mathrm{ml} / 10^{6}$ cells respectively) vs. controls $\left(90 \pm 66 \mathrm{pmol} / \mathrm{ml} / 10^{6}\right.$ cells, $\left.\mathrm{P}<0001\right)$ at isoproterenol $10^{-5} \mathrm{mM}$ stimulus (Fig. $1 \mathrm{~A}$ and $\mathrm{B}$, respectively).

OA patients with severity KL grade $4(n=17)$ presented a smaller response than lower KL severity grades $(n=6)(38 \pm 21$ and $61 \pm 42 \mathrm{pmol} / \mathrm{ml} / 10^{6}$ cells at isoproterenol $10^{-5} \mathrm{mM}$ stimulus, respectively, $\mathrm{P}=0,06$ ) (Fig. $1 \mathrm{~A})$. We observed a relevant $(67 \%)$ and significant reduction in cAMP increase in KL grade 4 with knee replacement patients $(n=12)$ compared with non-surgery patients $(\mathrm{n}=5)\left(30 \pm 14 \mathrm{vs} .52 \pm 23 \mathrm{pmol} / \mathrm{ml} / 10^{6}\right.$ cells, respectively, $\mathrm{P}=0046)$.

Cirrhotic patients have a significant decrease in $\beta 2 \mathrm{AR}-$ mediated AC activity stimulation, similar in patients with primary or secondary prophylaxis and in responder or non-responder cirrhotic patients (Fig. 1B). 
Table II. Polymorphisms and allele frequencies of $\beta 2 A R$ genotype analyzed.

\begin{tabular}{|c|c|c|c|c|c|c|c|}
\hline \multirow[b]{2}{*}{ SNP } & \multirow[b]{2}{*}{ Control } & \multicolumn{3}{|c|}{ Osteoarthritis } & \multicolumn{3}{|c|}{ Liver cirrhosis } \\
\hline & & $\begin{array}{l}\text { Naïve joint } \\
\text { replacement }\end{array}$ & $\begin{array}{l}\text { Knee joint } \\
\text { replacement }\end{array}$ & Total & Responder & Non-responder & Total \\
\hline \multicolumn{8}{|l|}{ Gly16Arg } \\
\hline $\mathrm{AA}$ & $19(73 \%)$ & $10(76 \%)$ & $9(64 \%)$ & $19(70 \%)$ & $9(43 \%)$ & $17(55 \%)$ & $26(58 \%)$ \\
\hline GA & 0 & 0 & 0 & 0 & $2(9.5 \%)$ & $3(10 \%)$ & $5(11 \%)$ \\
\hline GG & $7(27 \%)$ & $3(24 \%)$ & $5(36 \%)$ & $8(30 \%)$ & $7(33 \%)$ & $7(22 \%)$ & $14(31 \%)$ \\
\hline Allele G (Gly 16) & $27 \%$ & $23 \%$ & $36 \%$ & $30 \%$ & $44 \%$ & $31 \%$ & $37 \%$ \\
\hline \multicolumn{8}{|l|}{ Gln27Glu } \\
\hline $\mathrm{CC}$ & $16(62 \%)$ & $9(69 \%)$ & $6(42 \%)$ & $15(58 \%)$ & $10(47 \%)$ & $15(48 \%)$ & $25(55 \%)$ \\
\hline $\mathrm{CG}$ & $6(23 \%)$ & $1(7 \%)$ & $5(36 \%)$ & $6(23 \%)$ & $6(28 \%)$ & $7(23 \%)$ & $13(29 \%)$ \\
\hline GG & $4(15 \%)$ & $2(14 \%)$ & $3(21 \%)$ & $5(19 \%)$ & $2(9,5 \%)$ & $5(16 \%)$ & $7(16 \%)$ \\
\hline Allele G (Glu27) & $27 \%$ & $19 \%$ & $42 \%$ & $31 \%$ & $28 \%$ & $31 \%$ & $30 \%$ \\
\hline \multicolumn{8}{|l|}{ Thr164Ile } \\
\hline $\mathrm{CC}$ & $21(81 \%)$ & $13(100 \%)$ & $12(92 \%)$ & $25(96 \%)$ & $17(81 \%)$ & $26(84 \%)$ & $43(96 \%)$ \\
\hline $\mathrm{CT}$ & $2(8 \%)$ & 0 & $1(7 \%)$ & $1(4 \%)$ & $1(65 \%)$ & $1(3 \%)$ & $2(4 \%)$ \\
\hline $\mathrm{TT}$ & $3(11 \%)$ & 0 & 0 & 0 & 0 & 0 & 0 \\
\hline Allele T (Thr164) & $15 \%$ & $0 \%$ & $4 \%$ & $2 \%$ & $3 \%$ & $2 \%$ & $2 \%$ \\
\hline
\end{tabular}

$\beta 2 \mathrm{AR}, \beta 2$ adrenoceptors; SNP, single-nucleotide polymorphism.

$\beta 2 A R$ genotyping. Table II shows the genotypes frequencies, alleles, and carrier states at amino acid positions 16, 27 and 164 of the $\beta 2 A R$ gene.

The distribution of expected and observed frequencies of the different genotypes at the different amino acid positions followed the Hardy-Weinberg equilibrium both in patients and controls. Minor allele frequencies in our Caucasian Spanish sample from Alicante Department of Health, General Hospital were Gly16 (allele G, 0, 24-0, 44), Glu27 (allele G, 0, 19-0, 38) and Ile164 (allele T, 0, 00-0, 15).

Carriage of Arg16, Gln27 and Ile164 was more prevalent in controls, OA and LC patients. Even though we observed some differences in allele frequency i.e., a higher frequency of $\mathrm{G}$ allele (Gly16) in LC patients, especially in responders; however, none of these differences were statistically significant probably due to the reduced sample size.

In global, subjects with any of the $\beta 2 A R$ SNPs analyzed shown a non-significant decrease in cAMP increase (mean $\pm \mathrm{SD}$ ) at isoproterenol $10^{-5} \mathrm{mM}$ vs. wild type (WT) (Fig. 2): In controls ( $94 \pm 70$ vs. $85 \pm 64 \mathrm{pmol} / \mathrm{ml} / 10^{6}$ cells, $\mathrm{P}=0.753), \mathrm{OA}\left(52 \pm 31\right.$ vs. $34 \pm 19 \mathrm{pmol} / \mathrm{ml} / 10^{6}$ cells, $\left.\mathrm{P}=0.054\right)$ and $\mathrm{LC}$ patients $\left(15 \pm 17\right.$ vs. $13 \pm 16 \mathrm{pmol} / \mathrm{ml} / 10^{6}$ cells, $\left.\mathrm{P}=0.718\right)$ (Fig. 3A). The prevalence of the different genotypes did not differed between patients according to any clinical variable in both models of chronic inflammation (Fig. 3B and C). Combination of Arg $16^{+}-\mathrm{G} \ln 27^{+}$shown a decreased cAMP increase stimulus in controls $(n=5), O A(n=13)$ and cirrhotic $(\mathrm{n}=6)\left(50 \pm 32,38 \pm 21\right.$ and $14 \pm 19 \mathrm{pmol} / \mathrm{ml} / 10^{6}$ cells, respectively, $\mathrm{P}=0.094$ ) (data not shown). The bigger decrease AC stimulus was evidenced for the $\operatorname{Arg} 16^{+}-\mathrm{Gln} 27^{+}$in controls $(48 \% \beta 2 \mathrm{AR}$ agonism stimulus blocked) and for Arg16-Gln $27^{+}$in OA (51\% agonism stimulus blocked). In cirrhotic (13\% agonism stimulus

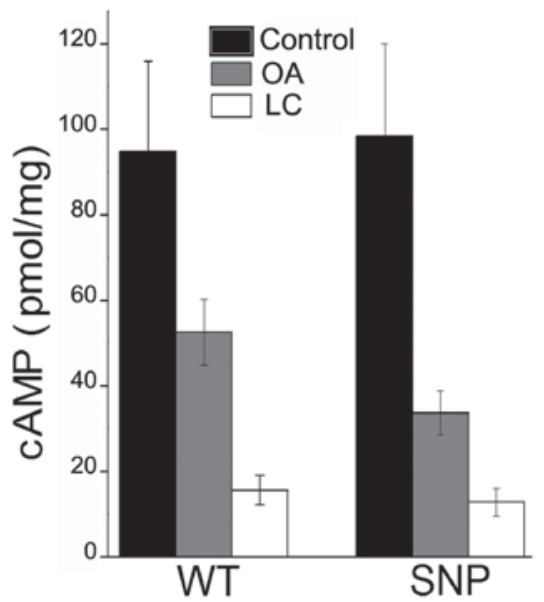

Figure 2. Adenylate-cyclase (AC) stimulus quantified by cAMP increase upon isoproterenol (ISO) treatment in peripheral blood mononuclear cells (PBMC) assays (Control, healthy volunteers; OA, osteoarthritis; LC, portal hypertension patients; ISO, $10^{-5} \mathrm{mM}$; WT, wild type; SNP, single-nucleotide polymorphism; for any polymorphism analysed)

blocked) the stimulus was the same for both Arg16-Gln $27^{+}$or $\operatorname{Arg} 16^{+}-\mathrm{G} \ln 27^{+}$.

$\beta 2 A R$ expression. Western blot detection of $\beta 2 \mathrm{AR}$ showed a decreased expression above 0.411 -fold for OA and 0.845 -fold for LC compared to healthy controls (data not shown).

\section{Discussion}

In this study we showed that the functional activity of PBMC $\beta 2 A R$ from patients with different types of chronic 

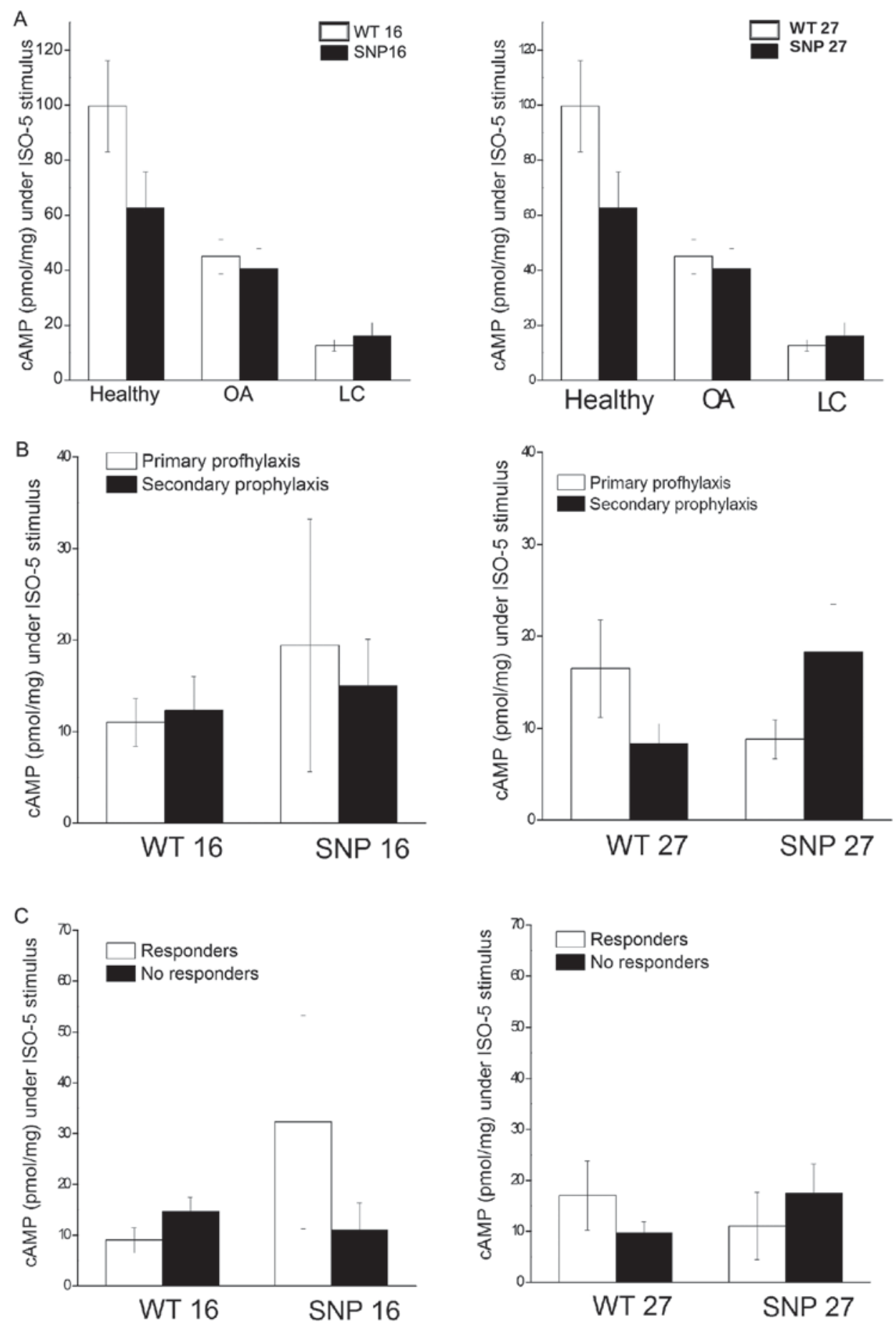

Figure 3. Dose response adenylate-cyclase (AC) stimulus, quantify by cAMP increases, by isoproterenol (ISO) treatment in peripheral blood mononuclear cells (PBMC) assays in (A) healthy volunteers (Healthy), osteoarthritis (OA) and liver cirrhosis (LC) patients; (B) in LC patients with primary or secondary prophylaxis; and (C) in responders and non responders LC patients. ISO, $10^{-5} \mathrm{mM}$; WT, wild type; SNP, single-nucleotide polymorphism; 16: carriage of Arg16 in rs1042713; 27, carriage of Glu27 in rs1042714.

inflammatory diseases (OA and LC) was significantly decreased in comparison with healthy volunteers. According to severity of diseases, OA patients receptor showed a higher loss of functionality in KL grade 4 and knee joint replacement. However, in LC patients there was no significant relation between $\beta 2 \mathrm{AR}$ functionality and severity of disease. These differences were not related to the $\beta 2 A R$ genotype analyzed.

We evaluated mononuclear cell $\beta 2 \mathrm{AR}$ responsiveness to isoproterenol to test the hypothesis that patients with chronic inflammatory diseases have a $\beta 2 \mathrm{AR}$ abnormality. In basal conditions (no pharmacologic stimulation of the receptor), intracellular cAMP levels showed no significant difference between OA and LC patients and controls. However, the response to $\beta 2 \mathrm{AR}$ stimulation with an agonist was significantly lower in patients. At high isoproterenol concentrations $\left(10^{-5} \mathrm{mM}\right) \mathrm{AC}$ activation response were a 50 and $85 \%$ lower than controls in OA and LC patients, respectively. These findings suggest that $\beta 2 \mathrm{AR}$ function itself is disturbed in patients 
with chronic inflammatory diseases. These blunted cAMP responses could be mainly caused by a decrease in receptor density (downregulation) (47) and/or by functional uncoupling (desensitization) $(48,49)$. Some studies suggested that $\beta 2 \mathrm{AR}$ responsiveness decreases with age subsequently decreasing $\beta 2 \mathrm{AR}$ function (50). No significant differences for age were found between controls and LC patients that could explained the differences in $\beta 2 \mathrm{AR}$ responsiveness. However, $\mathrm{OA}$ is an age-related disorder and OA patients in our study were significantly older than control and LC groups, we could not discard that differences in $\beta 2 \mathrm{AR}$ function are due to the advanced age in OA individuals, so further studies with age matched controls should be performed.

Previous studies showed that $\beta 2 \mathrm{AR}$ density and increase in intracellular cAMP levels in response to stimulation were decreased on PBMC in patients with chronic joint diseases $(51,52)$. Wahle et al $(53)$ showed a reduction of $\beta 2 \mathrm{AR}$ densities on B lymphocytes mirrored by an impaired intracellular cAMP generation in patients with chronic rheumatic diseases (RA, systemic lupus erythematosus, and systemic sclerosis) and chronic muscle pain disorders such as fibromyalgia and regional myofascial pain $(48,54,55)$. It is not clear whether this phenomenon occurs in response to the inflammatory process or precedes exacerbations of chronic rheumatic diseases. According to this, in our study, receptor levels were decreased above $41 \%$ for OA and $85 \%$ for LC compared to healthy standard, in a similar way that percentage of receptor agonism stimulus reduction.

Agonist binding to the $\beta 2 \mathrm{AR}$ causes the receptor to interact with and activate G-protein, which in turns activates AC. AC catalyzes the conversion of adenosine triphosphate (ATP) to cAMP activating dependent protein kinase. This results in phosphorylation of particular proteins and specific actions that depend on the cells and tissue (56). Then continuous stimulation of $\beta 2 \mathrm{AR}$ on PBMC, by elevated circulating catecholamine, may trigger a sympathetic adaptive mechanism.

Animal studies indicated that prior elevation of adrenaline and repeated stress down-regulate sympathetic responses to new stress, whereas prior exposure to $\beta 2 \mathrm{AR}$ agonist and intensive exercise reduce beta-adrenergic sensitivity $(57,58)$. Norepinephrine is released locally from sympathetic nerve terminals in synapse like junctions with immune cells and could exert down regulatory autocrine effects counteracting the chronicity of the disease in the inflamed joint synovium (59), determining for example, the disease onset, progression, and severity in RA and and OA (1,11-13). In the chronic phase of RA, the SNS has a strong anti-inflammatory role, reducing both bone destruction and inflammation in RA (60). Very similar effects were described in two models of chronic inflammatory bowel disease as Cohn's disease and diverticulitis (61).

Our data shows that patients with cirrhosis, varices and clinical decompensation had a reduced $\beta 2 \mathrm{AR}$ signalling in PBMC, suggesting the existence of changes of this cellular signalling pathway associated to the progression of this pathology. New studies with higher sample size are needed to clarify if this phenomenon could be considered as a molecular biomarker.

In our study, impairment of $\beta 2 \mathrm{AR}$ occurs in an independent way of the genetic profile. $\beta 2 \mathrm{AR}$ decreased functionality is not correlated to the presence of any SNP analyzed. A number of polymorphisms of the $\beta 2 \mathrm{AR}$ have been described that appear to alter the behaviour of the receptor following agonist exposure. These include Arg16Gly, Glu27Gln, and Thr164lle. Our sample has an Arg16 and Glu27 similar frequency to those showed in different Caucasian populations $(\operatorname{Arg} 16(0,38-0,46)$, Glu27 $(0,35-0,46)$ and Ile164 $(0,02-0,04))(62,63)$.

Presence of Glu27 (allele G) is associated with a decreased agonist-promoter down-regulation, less receptor desensitization being more sensitive to endogenous catecholamine and showing a greater susceptibility to stress-induced augmentation of visceral and somatic sensory function. On the contrary Gly16 (allele G) showed an increased receptor desensitization and Ile164 (allele T) a decreased affinity agonist binding $(64,65)$. In this way, previous results have shown that SNPs at Arg $16^{+}-\mathrm{Glu} 27^{+}$can modulated disease activity in RA, asthma and myasthenia gravis $(38,66,67)$. In our sample, severity of disease was not associated with any particular genotype. Subjects (OA and controls) with sustained ability to cAMP reacted to isoproterenol stimulus evidencing the highest cAMP blockade for the Gln27. Other studies in asthma had shown that Glu27 avoid downregulation and thus, it was associated with less reactive airways (68).

The Gly16 receptor variant downregulates to a greater extent and is associated with increased airway hyperactivity and greater susceptibility to stress-induced augmentation of visceral and somatic sensory function, compared with those homozygous for Arg16 (39). The receptors homozygous for Ile164 had markedly decreased ligand binding and coupling properties compared with those homozygous for Thr164. However, an individual can be homozygous or heterozygous for given polymorphisms, and large populations will have to be analysed to determine their importance on clinical phenotypes (69).

Although the amount of adrenergic receptor on lymphocytes has been shown to be related to the number of adrenergic receptors on heart tissue (70), future studies should employ a more direct assessment on liver and joint. A definitive evaluation of the relationship between the effects of $\beta 2 A R$ polymorphism and functionality requires large prospective multicenter trials to enable simultaneous consideration of single and multiple genotypes.

In conclusion, decreased $\beta 2 \mathrm{AR}$ functionality in patients with OA and LC was independent of patient's $\beta 2 A R$ genotype.

\section{Acknowledgements}

We would like to thank to Paula Giménez Martínez from the CIBERehd for her technical support with the EIA and cell culture and Bioiberica (Barcelona) for the financial support to develop this project.

\section{References}

1. Baerwald $\mathrm{CG}$, Burmester GR and Krause A: Interactions of autonomic nervous, neuroendocrine, and immune systems in rheumatoid arthritis. Rheum Dis Clin North Am 26: 841-857, 2000.

2. Bergquist J, Tarkowski A, Ekman R and Ewing A: Discovery of endogenous catecholamines in lymphocytes and evidence for catecholamine regulation of lymphocyte function via an autocrine loop. Proc Natl Acad Sci USA 91: 12912-12916, 1994.

3. Lorton D, Lubahn C and Bellinger DL: Potential use of drugs that target neural-immune pathways in the treatment of rheumatoid arthritis and other autoimmune diseases. Curr Drug Targets Inflamm Allergy 2: 1-30, 2003. 
4. Felsner P, Hofer D, Rinner I, Mangge H, Gruber M, Korsatko W and Schauenstein $\mathrm{K}$ : Continuous in vivo treatment with catecholamines suppresses in vitro reactivity of rat peripheral blood T-lymphocytes via alpha-mediated mechanisms. J Neuroimmunol 37: 47-57, 1992.

5. Elenkov IJ, Papanicolaou DA, Wilder RL and Chrousos GP: Modulatory effects of glucocorticoids and catecholamines on human interleukin-12 and interleukin-10 production: Clinical implications. Proc Assoc Am Physicians 108: 374-381, 1996.

6. Panina-Bordignon P, Mazzeo D, Lucia PD, D'Ambrosio D, Lang R, Fabbri L, Self C and Sinigaglia F: Beta2-agonists prevent Th1 development by selective inhibition of interleukin 12. J Clin Invest 100: 1513-1519, 1997.

7. Hernández FT, Zapater P, De-Madaria E, Palazón JM, Pascual S, Irurzun J, Such J, Perez-Mateo M and Horga JF: Functional status of beta-2-adrenoceptor in isolated membranes of mature erythrocytes from patients with cirrhosis and oesophageal varices. Vascul Pharmacol 44: 464-468, 2006.

8. Brodde OE, Zerkowski HR, Doetsch N, Motomura S, Khamssi M and Michel MC: Myocardial beta-adrenoceptor changes in heart failure: Concomitant reduction in beta 1- and beta 2-adrenoceptor function related to the degree of heart failure in patients with mitral valve disease. J Am Coll Cardiol 14: 323-331, 1989.

9. Yu XY, Lin SG, Wang XM, Liu Y, Zhang B, Lin QX, Yang M and Zhou SF: Evidence for coexistence of three beta-adrenoceptor subtypes in human peripheral lymphocytes. Clin Pharmacol Ther 81: 654-658, 2007.

10. Xu B, Yi Q, Pirskanen R, Matell G, Eng H and Lefvert AK: Decreased beta2-adrenergic receptor density on peripheral blood mononuclear cells in myasthenia gravis. J Autoimmun 10 401-406, 1997.

11. Levine JD, Goetzl EJ and Basbaum AI: Contribution of the nervous system to the pathophysiology of rheumatoid arthritis and other polyarthritides. Rheum Dis Clin North Am 13: 369-383, 1987.

12. Härle P, Möbius D, Carr DJ, Schölmerich J and Straub RH: An opposing time-dependent immune-modulating effect of the sympathetic nervous system conferred by altering the cytokine profile in the local lymph nodes and spleen of mice with type II collagen-induced arthritis. Arthritis Rheum 52: 1305-1313, 2005.

13. Härle P, Pongratz G, Albrecht J, Tarner IH and Straub RH: An early sympathetic nervous system influence exacerbates collagen-induced arthritis via CD4+CD25+ cells. Arthritis Rheum 58: 2347-2355, 2008

14. Malfait AM, Malik AS, Marinova-Mutafchieva L, Butler DM, Maini RN and Feldmann M: The beta2-adrenergic agonist salbutamol is a potent suppressor of established collagen-induced arthritis: Mechanisms of action. J Immunol 162: 6278-6283, 1999.

15. Lorton D, Bellinger DL, Schaller JA, Shewmaker E, Osredkar T and Lubahn C: Altered sympathetic-to-immune cell signaling via $\beta_{2}$-adrenergic receptors in adjuvant arthritis. Clin Dev Immunol 2013: 764395, 2013.

16. Neuhuber WL and Tiegs G: Innervation of immune cells: Evidence for neuroimmunomodulation in the liver. Anat Rec A Discov Mol Cell Evol Biol 280: 884-892, 2004.

17. Tiegs G, Bang R and Neuhuber WL: Requirement of peptidergic sensory innervation for disease activity in murine models of immune hepatitis and protection by beta-adrenergic stimulation. J Neuroimmunol 96: 131-143, 1999.

18. Grässel SG: The role of peripheral nerve fibers and their neurotransmitters in cartilage and bone physiology and pathophysiology. Arthritis Res Ther 16: 485, 2014.

19. Eitner A, Pester J, Nietzsche S, Hofmann GO and Schaible HG The innervation of synovium of human osteoarthritic joints in comparison with normal rat and sheep synovium. Osteoarthritis Cartilage 21: 1383-1391, 2013

20. Najafipour $\mathrm{H}$ and Niazmand S: Alteration in alpha- and betaadrenoceptor profile of rabbit-knee-joint blood vessels due to chronic inflammation. Pflugers Arch 453: 23-32, 2006.

21. Beckmann J, Knödl M, Bauser E, Tingart M, Grifka J and Straub RH: Loss of sympathetic nerve fibers in vital intertrochanteric bone cylinders lateral to osteonecrosis of the femoral head. Joint Bone Spine 80: 188-194, 2013.

22. Fernandes JC, Martel-Pelletier J and Pelletier JP: The role of cytokines in osteoarthritis pathophysiology. Biorheology 39: 237-246, 2002

23. Malemud CJ: Anticytokine therapy for osteoarthritis: Evidence to date. Drugs Aging 27: 95-115, 2010.
24. D'Amico G and Luca A: Natural history. Clinical-haemodynamic correlations. Prediction of the risk of bleeding. Baillieres Clin Gastroenterol 11: 243-256, 1997.

25. Sanders VM: The beta2-adrenergic receptor on T and B lymphocytes: Do we understand it yet? Brain Behav Immun 26: 195-200, 2012.

26. Biecker E: Portal hypertension and gastrointestinal bleeding: Diagnosis, prevention and management. World J Gastroenterol 19: 5035-5050, 2013.

27. Pateron D, Tazi KA, Sogni P, Heller J, Chagneau C, Poirel O, Philippe M, Moreau R and Lebrec D: Role of aortic nitric oxide synthase 3 (eNOS) in the systemic vasodilation of portal hypertension. Gastroenterology 119: 196-200, 2000.

28. Tazi KA, Barrière E, Moreau R, Heller J, Sogni P, Pateron D, Poirel O and Lebrec D: Role of shear stress in aortic eNOS up-regulation in rats with biliary cirrhosis. Gastroenterology 122 : 1869-1877, 2002

29. Karadsheh $\mathrm{Z}$ and Allison $\mathrm{H}$ : Primary prevention of variceal bleeding: Pharmacological therapy versus endoscopic banding. N Am J Med Sci 5: 573-579, 2013.

30. Lemaitre RN, Heckbert SR, Sotoodehnia N, Bis JC, Smith NL, Marciante KD, Hindorff LA, Lange LA, Lumley TS, Rice KM, et al: beta1- and beta2-adrenergic receptor gene variation, beta-blocker use and risk of myocardial infarction and stroke. Am J Hypertens 21: 290-296, 2008.

31. Heckbert SR, Hindorff LA, Edwards KL, Psaty BM, Lumley T, Siscovick DS, Tang Z, Durda JP, Kronmal RA and Tracy RP: Beta2-adrenergic receptor polymorphisms and risk of incident cardiovascular events in the elderly. Circulation 107: 2021-2024, 2003.

32. Sotoodehnia N, Siscovick DS, Vatta M, Psaty BM, Tracy RP, Towbin JA, Lemaitre RN, Rea TD, Durda JP, Chang JM, et al: Beta2-adrenergic receptor genetic variants and risk of sudden cardiac death. Circulation 113: 1842-1848, 2006.

33. Stanzione R, Di Angelantonio E, Evangelista A, Barbato D, Marchitti S, Zanda B, Pirisi A, Quarta G, Volpe M and Rubattu S: Beta2-adrenergic receptor gene polymorphisms and risk of ischemic stroke. Am J Hypertens 20: 657-662, 2007.

34. Lanfear DE, Jones PG, Marsh S, Cresci S, McLeod HL and Spertus JA: Beta2-adrenergic receptor genotype and survival among patients receiving beta-blocker therapy after an acute coronary syndrome. JAMA 294: 1526-1533, 2005.

35. Tan S, Hall IP, Dewar J, Dow E and Lipworth B: Association between beta 2-adrenoceptor polymorphism and susceptibility to bronchodilator desensitisation in moderately severe stable asthmatics. Lancet 350: 995-999, 1997.

36. Gianfagna F, Cugino D, Ahrens W, Bailey ME, Bammann K, Herrmann D, Koni AC, Kourides Y, Marild S, Molnár D, et al: Understanding the links among neuromedin U gene, beta2-adrenoceptor gene and bone health: An observational study in European children. PLoS One 8: e70632, 2013.

37. Malysheva O, Pierer M, Wagner U, Wahle M, Wagner U and Baerwald CG: Association between beta2 adrenergic receptor polymorphisms and rheumatoid arthritis in conjunction with human leukocyte antigen (HLA)-DRB1 shared epitope. Ann Rheum Dis 67: 1759-1764, 2008.

38. Xu B, Arlehag L, Rantapää-Dahlquist SB and Lefvert AK: Beta2-adrenergic receptor gene single-nucleotide polymorphisms are associated with rheumatoid arthritis in northern Sweden. Scand J Rheumatol 33: 395-398, 2004.

39. Kushnir VM, Cassell B, Gyawali CP, Newberry RD, Kibe P, Nix BD, Sabzpoushan A, Kanuri ND and Sayuk GS: Genetic variation in the beta-2 adrenergic receptor (ADRB2) predicts functional gastrointestinal diagnoses and poorer health-related quality of life. Aliment Pharmacol Ther 38: 313-323, 2013.

40. Kellgren JH and Lawrence JS: Radiological assessment of osteo-arthrosis. Ann Rheum Dis 16: 494-502, 1957.

41. Bosch J, Abraldes JG, Albillos A, Aracil C, Bañares R, Berzigotti A, Calleja JL, de la Peña J, Escorsell A, García-Pagán JC, et al: Portal hypertension: Recommendations for evaluation and treatment: Consensus document sponsored by the Spanish association for the study of the liver (AEEH) and the biomedical research network center for liver and digestive diseases (CIBERehd). Gastroenterol Hepatol 35: 421-450, 2012 (In Spanish).

42. Sondergaard SB, Knudsen JH and Christensen NJ: Regulation of cAMP in a lymphocyte preparation isolated from peripheral venous blood in human subjects: The significance of residual thrombocytes, noradrenaline and prostaglandins. Clin Sci (Lond) 95: 377-383, 1998 
43. Drysdale CM, McGraw DW, Stack CB, Stephens JC, Judson RS, Nandabalan K, Arnold K, Ruano G and Liggett SB: Complex promoter and coding region beta 2 -adrenergic receptor haplotypes alter receptor expression and predict in vivo responsiveness. Proc Natl Acad Sci USA 97: 10483-10488, 2000.

44. Belfer I, Buzas B, Hipp H, Phillips G, Taubman J, Lorincz I, Evans C, Lipsky RH, Enoch MA, Max MB and Goldman D: Haplotype-based analysis of alpha 2A, 2B, and 2C adrenergic receptor genes captures information on common functional loci at each gene. J Hum Genet 50: 12-20, 2005.

45. Campello L, Esteve-Rudd J, Bru-Martinez R, Herrero MT, Fernández-Villalba E, Cuenca N and Martín-Nieto J: Alterations in energy metabolism, neuroprotection and visual signal transduction in the retina of Parkinsonian, MPTP-treated monkeys PLoS One 8: e74439, 2013.

46. Garcia-Tsao G, Sanyal AJ, Grace ND and Carey W; Practice Guidelines Committee of the American Association for the Study of Liver Diseases; Practice Parameters Committee of the American College of Gastroenterology: Prevention and management of gastroesophageal varices and variceal hemorrhage in cirrhosis. Hepatology 46: 922-938, 2007.

47. Jeanningros R, Mazzola P, Azorin JM, Samuelian-Massa C and Tissot R: Beta-adrenoceptor density of intact mononuclear leukocytes in subgroups of depressive disorders. Biol Psychiatry 29. 789-798, 1991.

48. Maekawa K, Twe C, Lotaif A, Chiappelli F and Clark GT: Function of beta-adrenergic receptors on mononuclear cells in female patients with fibromyalgia. J Rheumatol 30: 364-368, 2003.

49. Leineweber K, Rohe P, Beilfuss A, Wolf C, Sporkmann H, Bruck H, Jakob HG, Heusch G, Philipp T and Brodde OE: G-protein-coupled receptor kinase activity in human heart failure: Effects of beta-adrenoceptor blockade. Cardiovasc Res 66: 512-519, 2005.

50. Scarpace PJ, Tumer N and Mader SL: Beta-adrenergic function in aging. Basic mechanisms and clinical implications. Drugs Aging 1: 116-129, 1991.

51. Krause A, Henrich A, Beckh KH, Von Wichert P and Baerwald C: Correlation between density of beta 2-adrenergic receptors on peripheral blood mononuclear cells and serum levels of soluble interleukin-2 receptors in patients with chronic inflammatory diseases. Eur J Clin Invest 22 (Suppl 1): S47-S51, 1992.

52. Baerwald C, Graefe C, Muhl C, Von Wichert P and Krause A: Beta 2-adrenergic receptors on peripheral blood mononuclear cells in patients with rheumatic diseases. Eur J Clin Invest 22 (Suppl 1): S42-S46, 1992

53. Wahle M, Kölker S, Krause A, Burmester GR and Baerwald CG Impaired catecholaminergic signalling of B lymphocytes in patients with chronic rheumatic diseases. Ann Rheum Dis 60 505-510, 2001.

54. Maekawa K, Kuboki T, Inoue E, Inoue-Minakuchi M, Suzuki K, Yatani H and Clark GT: Function of beta 2-adrenergic receptors in chronic localized myalgia. J Orofac Pain 17: 140-144, 2003.

55. Maekawa K, Clark GT and Kuboki T: Intramuscular hypoperfusion, adrenergic receptors, and chronic muscle pain. J Pain 3: 251-260, 2002

56. Lefkowitz RJ, Caron MG and Stiles GL: Mechanisms of membrane-receptor regulation. Biochemical, physiological, and clinical insights derived from studies of the adrenergic receptors. N Engl J Med 310: 1570-1579, 1984.
57. de Galan BE, Rietjens SJ, Tack CJ, van der Werf SP, Sweep CG, Lenders JW and Smits P: Antecedent adrenaline attenuates the responsiveness to but not the release of counterregulatory hormones during subsequent hypoglycemia. J Clin Endocrinol Metab 88: 5462-5467, 2003.

58. Baerwald CG, Laufenberg M, Specht T, von Wichert P, Burmester GR and Krause A: Impaired sympathetic influence on the immune response in patients with rheumatoid arthritis due to lymphocyte subset-specific modulation of beta 2-adrenergic receptors. Br J Rheumatol 36: 1262-1269, 1997.

59. Ader R, Cohen N and Felten D: Psychoneuroimmunology: Interactions between the nervous system and the immune system. Lancet 345: 99-103, 1995.

60. Capellino S, Cosentino M, Wolff C, Schmidt M, Grifka J and Straub RH: Catecholamine-producing cells in the synovial tissue during arthritis: Modulation of sympathetic neurotransmitters as new therapeutic target. Ann Rheum Dis 69: 1853-1860, 2010.

61. Straub RH, Grum F, Strauch U, Capellino S, Bataille F, Bleich A, Falk W, Schölmerich J and Obermeier F: Anti-inflammatory role of sympathetic nerves in chronic intestinal inflammation. Gut 57: 911-921, 2008

62. Brodde OE, Bruck H and Leineweber K: Cardiac adrenoceptors: Physiological and pathophysiological relevance. J Pharmacol Sci 100: 323-337, 2006 .

63. Kirstein SL and Insel PA: Autonomic nervous system pharmacogenomics: A progress report. Pharmacol Rev 56: 31-52, 2004.

64. Diatchenko L, Anderson AD, Slade GD, Fillingim RB, Shabalina SA, Higgins TJ, Sama S, Belfer I, Goldman D, Max MB, et al: Three major haplotypes of the beta2 adrenergic receptor define psychological profile, blood pressure, and the risk for development of a common musculoskeletal pain disorder. Am J Med Genet B Neuropsychiatr Genet 141B: 449-462, 2006.

65. Small KM, McGraw DW and Liggett SB: Pharmacology and physiology of human adrenergic receptor polymorphisms. Annu Rev Pharmacol Toxicol 43: 381-411, 2003.

66. Zuurhout MJ, Vijverberg SJ, Raaijmakers JA, Koenderman L, Postma DS, Koppelman GH and Maitland-van der Zee AH: Arg16 ADRB2 genotype increases the risk of asthma exacerbation in children with a reported use of long-acting $\beta 2$-agonists: Results of the PACMAN cohort. Pharmacogenomics 14: 1965-1971, 2013

67. Bengtsson K, Orho-Melander M, Melander O, Lindblad U, Ranstam J, Råstam L and Groop L: Beta(2)-adrenergic receptor gene variation and hypertension in subjects with type 2 diabetes. Hypertension 37: 1303-1308, 2001.

68. Martinez FD, Graves PE, Baldini M, Solomon S and Erickson R: Association between genetic polymorphisms of the beta2-adrenoceptor and response to albuterol in children with and without a history of wheezing. J Clin Invest 100: 3184-3188, 1997.

69. Gjesing AP, Andersen G, Burgdorf KS, Borch-Johnsen K, Jørgensen T, Hansen T and Pedersen O: Studies of the associations between functional beta2-adrenergic receptor variants and obesity, hypertension and type 2 diabetes in 7,808 white subjects. Diabetologia 50: 563-568, 2007.

70. Qing F, Rahman SU, Hayes MJ, Rhodes CG, Ind PW, Jones T and Hughes JM: Effect of long-term beta2-agonist dosing on human cardiac beta-adrenoceptor expression in vivo: Comparison with changes in lung and mononuclear leukocyte beta-receptors. J Nucl Cardiol 4: 532-538, 1997. 